образовательными потребностям своих учеников, находя самые продуктивные методы работы в классе. Результативность работы учителя - Профессионала в полной мере зависит от регулярного повышении своей квалификации и дальнейшего профессионального роста. В этом начинании учителя поддерживают местные образовательные агентства, профессиональные ассоциации и «образовательные органы оценки качества работы учителей и профессионального обучения» через систему лицензирования (или сертификации). Они же выдвигают кандидатуру учителя Профессионала к следующему этапу - Аттестации.

Педагог, готовый к процессу сертификации или аттестации должен доказать педагогическому сообществу, что его деятельность полностью соответствует стандартам, разработанным Национальным Советом по Сертификации Преподавателей. Этот этап карьеры учителя отмечен профессиональной ответственностью перед своими учениками, коллегами и педагогической профессией как таковой. Коллеги кандидата имеют право рекомендовать пройти процесс сертификации самых опытных, владеющих передовыми технологиями преподавателей, способных к динамическому развитию своих профессиональных навыков. Сегодня, преподаватели, прошедшие аттестацию свидетельствуют о положительном влиянии процесса сертификации на их практику. Они часто отмечают, что весь процесс подготовки к сертификации был самым продуктивным профессиональным опытом, который у них когда-либо был. Тем не менее, в тех сферах, где сертификация является нормой, это естественный процесс саморазвития как профессионала, с самого первого дня.

По своей сути стандартизация и сертификация в области образования служит платформой профессионального развития не только учителя, но и школьного руководства. Учителя, прошедшие сертификацию, получившие статус Аттестованного учителя (Board-certified Teacher) на уровне школы, округа, штата могут распространять свой передовой опыт среди коллег, становиться лидерами в своей профессии, занимать руководящие посты любого уровня, влиять на положительный имидж общественно значимой профессии учителя [3].

На наш взгляд, самая важная характеристика профессиональных стандартов США - это формирование требований к качествам педагога и его деятельности как на входе в профессию, так и на разных ее этапах для достижения наивысшего мастерства. По сути, стандарт сопровождает учителя, создавая условия для его рефлексивной деятельности как профессионала.

$$
* * *
$$

1. Нестеренко В. Г. Современное состояние и тенденции развития педагогического образования за рубежом [Электронный ресурс]: монография/ В. Г. Нестеренко- Электрон. текстовые данные.Саратов: Ай Пи Эр Медиа, 2017.- 142 с.- Режим доступа: http://www.iprbookshop.ru/68924.html.— ЭБС «IPRbooks», 128 C.

2. Thorpe, R. (2014). Sustaining the teaching profession. New England Journal of Public Policy, 26(1), 116.).|

3. What Teachers Should Know and Be Able to Do./ National Board for Professional Teaching Standards. Режимдоступа: http://www.nbpts.org

\title{
Соколова И.А.
}

Диагностика показателей физического развития обучащихся начальных классов

Курский государственный университет (Россия, Курск)

doi 10.18411/spc-04-04-2018-11

idsp 000001:spc-04-04-2018-11

Физическоеразвитиеребенка - это совокупностьморфологических и функциональныхсвойстворганизма, характеризующихпроцессего развития в каждый возрастнойпериод. Физическое развитие - это динамичный процесс, характеризующий 
параметры роста и развития ребенка в настоящее время, которые рассматриваются как один из основных и информативных критериев здоровья детского населения [1].Физическое развитие является одним из основных и информативных показателей здоровья детей, требующих систематического наблюдения. Оценка физического развития - обязательная составляющая программ медицинских осмотров [2]. Для выявления особенностей физического развития детей проводится антропометрическое обследование, включающее соматометрические, соматоскопические и физиометрические признаки (показатели).

На кафедре медико-биологических дисциплин КГУ было проведено исследование, основная цель которого - комплексная оценка показателей физического развития младших школьников Курского района Курской области. В исследовании приняли участие 317 обучащихся начальных классов шести общеобразовательных учебных учреждений Курского района Курской области. Для характеристики физического развития школьников младших классов использовались антропометрически показатели (длина и масса тела, окружной грудной клетки, жизненная емкость легких, кистевая динамометрия) и индексы (индекс Эрисмана, индекс Кетле и индекс Пинье). Получение комплексных данных об антропометрических и соматотипологических особенностях детей начальной школы Курского района Курской области необходимо для оценки качества общего здоровья и благополучия населения данного региона.

Результаты диагностики физического развития младших школьников Курского района Курской области:

Средний весовой показатель мальчиков составил 34,8 кг; девочек - 31,9 кг; средний рост девочек составил 134,5 см; мальчиков - 133,67см. Средние показатели, полученные при измерении окружности грудной клетки, составили у мальчиков 62,8 см, у девочек - $61,83 \mathrm{~cm}$.

В результате оценки физиометрических признаков были получены следующие данные: средний показатель жизненной емкости легких у мальчиков был достоверно выше и составил 1223,2 л; у девочек - 1178,5 л; показатели силы кисти мальчиков 9,5кг и 9,1 кг- у девочек.

По индексу Эрисмана пропорциональная грудная клеткавстречается у 17,5\% обследуемых, 32,0\% учащихся начальных классовимеютширокуюпоформе грудную клетку и 50,5\% - узкую. В цифровом выражении у мальчиков значениеданногоиндексасоставило в среднем 7,07, у девочек - 7,75.

У 73,7\% обследуемых девочек индекса массы тела (Кетле) соответствует норме; хроническаяэнергетическаянедостаточность отмечается в $12,7 \%$, наличиелишнеговеса - в $12,7 \%$, ожирение - в 1\%. У мальчиков норма массы тела выявлена в 75,0\% случаев, хроническая энергетическая недостаточность - в $2 \%$, наличие лишнего веса - в $16 \%$, ожирение - в 7\%.

Согласно результатамвычисленияиндексаПинье у $57 \%$ мальчиков преобладает атлетический тип телосложения, у $25 \%$ - астенический и у $18 \%$ - пикнитический .Средидевочекнаиболеечастовстречаетсяпикнетический (нормостенический) соматотип $(37 \%)$ и атлетический (39\%), реже астенический $(24 \%)$.

Полученные в ходе проведения исследования данные позволяют сделать следующие выводы: индекс пропорциональности грудной клетки (Эрисмана) показал, что у мальчиков превалирует широкогрудость, у девочек узкогрудость, а гармоничное развитие отмечается всего у 17,5\% учащихся; значения индекса массы тела (Кетле) ниже нормы зафиксированы у 7,33\% школьников; у $14,33 \%$ диагностируетсяналичиелишнеговеса, а у 3,95\% - ожирение, у 74,3\% - норма массы тела; по результатам вычисления индекса Пинье выявлено, что у $48 \%$ учащихся тип телосложения определяется как атлетический, у $27,5 \%$ - пикнитический и у $24,5 \%$ астенический. 
Исследуемые показатели физического развития у мальчиков и девочек не имели достоверных отличий, за исключением данных полученных при измерении массы тела, где мальчики оказались тяжелее своих ровесниц-девочек (ИМТ, указывающий на ожирение, диагностирован только у мальчиков). Проведение подобных исследований необходимо для повышения эффективности профилактических и оздоровительных мероприятий в рамках учебно-воспитательных программ в период обучения.

$$
* * *
$$

1. Руденко Н. Н. Влияние физического развития на формирование соматической патологии (обзор литературы) / Н. Н. Руденко, И. Ю. Мельникова // Вестн. СПбМАПО. 2009. Т. 1, № 2. С. 94-104.

2. Яцун С. М., Соколова И. А., Лунева Н.В. Физическое развитие как объективный показатель состояния здоровья обучающихся /С.М. Яцун, И.А. Соколова, Н.В. Лунева //Здоровье и образование в 21 веке. 2017.T.19 [2]. С. 26-30

\section{Феуерман В.В., Матлубов А.А. \\ Физическая подготовка в футболе на тренировочном этапе как фактор эффективной технической оснащённости юных футболистов}

Крымский федеральный университет имени В.И. Вернадского (Россия, Симферополь)

doi 10.18411/spc-04-04-2018-12

idsp 000001:spc-04-04-2018-12

\section{Аннотация}

Рассмотрен важнейший фактор эффективного повышения уровня технической подготовленности юных футболистов, на тренировочном этапе спортивной подготовки - должный уровень физической подготовленности. Научно обоснована необходимость повышения уровня скоростных и скоростно-силовых способностей юных футболистов 13-14 лет, на тренировочном этапе спортивной подготовки, при совершенствовании базового технического приёма - «Одиннадцати метровый удар (пенальти)».

Ключевые слова: футбол, физическая подготовленность, техническая подготовленность, скоростно-силовые способности, учебно-тренировочный процесс, юные футболисты.

Актуальность. В своей публикации П.Н. Казаков отмечает: «Футбол командная игра, но на начальном этапе многолетней подготовки командные задачи вторичны. На первый план выходит индивидуальное обучение техническим приемам и развитие двигательных способностей юных футболистов. В футболе будущего особенно востребованными окажутся игроки, индивидуальное техническое мастерство, которых позволит им эффективно играть в насыщенных соперниками зонах поля» [1].

По мнению ведущих специалистов в сфере спорта - Ю.Д. Железняка, Ю.М. Портнова, Ю.Ф. Курамшина и Ж.К. Холодова: «Развитие скоростных способностей важнейшая составляющая физической подготовки футболиста. Определение понятия быстроты в футболе значительно шире, чем во многих других видах спорта» $[4,5,6]$.

Осташев П.В. в учебном пособии утверждает: «Футбол - это игра со своими законами и правилами. Кроме того, в футболе действуют общие закономерности и принципы подготовки спортсменов, свойственные всем видам спорта. И поэтому тренировочный процесс должен строиться на основе этих закономерностей и принципов. Есть, например, закономерности освоения технических приемов. Одна из них заключается в том, что в основе эффективной техники лежит хорошая внутримышечная и межмышечная координация. Такая координация развивается и совершенствуется при многократном повторении одного и того же технического приема вначале в стандартных, а потом и в самых разнообразных условиях. В дворовых условиях старого футбола этот закон действовал неотвратимо: за несколько часов игры 